\title{
Egg introduction: differential allergic responses
}

This article was published in the following Dove Press journal:

Journal of Asthma and Allergy

5 April 2017

Number of times this article has been viewed

\section{Amrita Dosanjh \\ Medical Center, Rady Childrens Hospital, San Diego, CA, USA}

Correspondence: Amrita Dosanjh Medical Center, Rady Childrens Hospital, San Diego, CA, USA

Tel +I 8584426 I 46

Email pulmdI@gmail.com
Abstract: The use of egg protein preparations in clinical trials to reduce the incidence of egg allergy among infants includes a number of preparations of egg. These include whole egg, egg white protein, and egg yolk preparations. The study of the differential immune responses to these allergenic proteins in comparison is suggested as a future research area of investigation.

Keywords: food allergy, egg allergy, clinical trial, atopy

\section{Introduction}

Hen's egg allergy is a common early-life food allergy. There are divergent results of early egg introduction on the subsequent development of egg sensitization, as noted in the JAMA article by Ierodiakonou et al. ${ }^{1}$ In their meta-analysis of five trials with 1915 participants, the study showed that the egg introduction between 4 and 6 months of age was associated with a lower risk of egg allergy compared to later introduction (relative risk $[\mathrm{RR}]=0.56, p=0.009$ ). In contrast though, four trials with 1786 participants showed no association between timing of egg introduction and egg sensitization. ${ }^{1}$ Sensitization and development of allergy are separate conditions.

One of the difficulties in the interpretation of egg introduction studies may be the form of the egg protein itself. There are studies utilizing egg yolk, egg white, and whole egg powder. Each is a distinct form of egg with its own allergenic properties.

\section{Discussion}

One of the first clinical studies of egg introduction introduced egg yolk to infants either before 3 weeks of age or after 6 months of age. ${ }^{2}$ The authors reported in both groups that infants developed allergic disease and that respiratory symptoms were common (6/13). The study was conducted without the benefit of modern allergy testing methods. Recently, two studies of egg introduction highlight that further study is needed to identify whether a subset of infants may benefit from early introduction of egg protein and whether the form of egg impacts the development of allergic disease.

A study by Bellach et al found no evidence that egg white powder (Vernum) introduced at 4-6 months of age prevents hen's egg sensitization or allergy. ${ }^{3}$ The authors report that among infants screened for the study, 16 were identified to already have responses to egg food challenge and that among these infants, 10 had anaphylactic reactions involving two organ systems. Four of the 16 infants had involvement of the respiratory or cardiovascular systems. Among the 383 infants not sensitized at 4-6 
months of age, 184 received Vernum. At 12 months of life, $5.6 \%$ in the early introduction group and $2.6 \%$ in the placebo group demonstrated egg sensitization $(p=0.24)$. This study showed that egg white powder used in early introduction did not significantly modify sensitization at 12 months of age.

In a study of 319 infants, randomized to receive whole egg powder $(n=165)$ between 4 and 6 months of age, there were fewer infants with egg white sensitization among the early introduction group (11\%) versus control group (20\%, $p<0.0001)$. In this study, 14 infants reacted to egg within 1 week of early introduction, despite a negative egg white skin test. ${ }^{4}$ In this study, whole egg powder was effective in reducing the sensitization to egg white at 12 months of age.

\section{Conclusion}

A subset of infants in the early introduction group or during food challenge screening will develop a clinical reaction. There are divergent results available regarding the usefulness of early egg introduction, but more studies comparing egg white, egg yolk, and whole egg powder may yield further insight on the potential modification of allergic responses to hen's egg.

\section{Disclosure}

The author reports no conflicts of interest in this work.

\section{References}

1. Ierodiakonou D, Gracia-Larsen V, Logan A, et al. Timing of allergenic food introduction to the infant diet and risk of allergic or autoimmune disease. JAMA. 2016;316:1181-1192.

2. Halpern S, Sellars W, Johnson R, Anderson D, Saperstein S, Reisch J. Development of childhood allergy in infants fed breast, soy, or cow milk. J Allergy Clin Immunol. 1973;51(3):139-151.

3. Bellach J, Schwarz V, Ahrens B, et al. Randomized placebo-controlled trial of hen's egg consumption for primary prevention in infants. JAllergy Clin Immunol. 2016. Epub ahead of print.

4. Tan JWL, Valerio C, Barnes EH, et al; BEAT Study Group. Early introduction of dietary egg reduced egg sensitization at 12 months of age in infants at risk of allergic disease. J Allergy Clin Immunol. 2016; 137(2 Suppl):AB398.
Journal of Asthma and Allergy

\section{Publish your work in this journal}

The Journal of Asthma and Allergy is an international, peer-reviewed open access journal publishing original research, reports, editorials and commentaries on the following topics: Asthma; Pulmonary physiology; Asthma related clinical health; Clinical immunology and the immunological basis of disease; Pharmacological interventions and

\section{Dovepress}

new therapies. This journal is included in PubMed. The manuscript management system is completely online and includes a very quick and fair peer-review system, which is all easy to use. Visit http://www. dovepress.com/testimonials.php to read real quotes from published authors. 